\title{
Being Black (and) Immigrant Students: When Race, Ethnicity, and Nativity Collide
}

\author{
Chrystal A. George Mwangi \\ University of Massachusetts Amherst \\ U. S. A. \\ Shelvia English \\ University of Maryland \\ U. S. A.
}

\begin{abstract}
While Black immigrants share some of the racialized experiences of native-Black Americans, they also have distinctive experiences. U.S. education presents an important environment to investigate these experiences as immigrants have the fastest growing child population and these children are increasingly entering the education system. This paper engages a systematic review of the growing body of literature centering on Black immigrants across the U.S. P-20 pipeline (preschool through graduate school). Findings reveal that the presentation of Black immigrants is incomplete in terms of the frameworks and research designs used to examine their educational experiences, pointing to a larger issue of a single narrative concerning this group.
\end{abstract}

KEYWORDS: Black immigrants, race, immigrant education, meta-analysis, systematic review, educational research

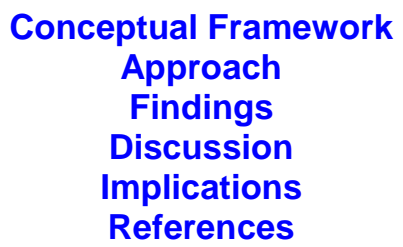

Appendix A: Inclusion/Exclusion Criterion

Appendix B: Dataset of Studies

Appendix C: Summary of Dataset Characteristics

Author Contact

The population of Black immigrants in the United States has tripled since the 1980s (Hernandez, 2012). In the past 10 to 15 years, the population grew from 2.4 to 3.8 million, indicating a 56\% increase (Anderson, 2015). While Black immigrants, particularly from Africa and the Caribbean, share some of the racialized experiences of native-Black Americans, they also have distinctive cultural contexts and identities. The U.S. education system presents an important environment to investigate these dynamics and experiences, as immigrants have 
the fastest growing child population and these children are increasingly entering the U.S. education pipeline (Portes \& Fernandez-Kelly, 2008). Twelve percent of all U.S. Black children from birth to age 10 have at least one foreign-born parent (Hernandez, 2012). At the college level, approximately $13 \%$ of all Black undergraduates are immigrants, a percentage that doubles and triples at the most selective colleges (Massey, Mooney, Torres, \& Charles, 2007). As Black immigrants' representation increases in U.S. education, likewise scholarship is seeing an increase of research published on their educational experiences. Yet, traditional Black identity development models and studies regarding the experiences of Black students often fail to identify how intersections of race, ethnicity, and nativity impact students who are both Black and immigrant (George Mwangi, 2014).

Rong and Brown (2002) published a review of scholarship on Black immigrants covering the period 1982-2002. The authors examined how racial socialization intersects with identity and sociocultural factors, such as class and social norms, to impact the educational approaches of Black immigrants. Given the growth of the Black immigrant population over the past 15 years (particularly the growth of African immigrants), as well as new work published in education journals since, it is important to revisit the experiences of this population. Thus, the purpose of this article is to conduct a critical and systematic review of contemporary research on the experiences of Black immigrants in the U.S. P-20 education pipeline (preschool through graduate school).

\section{Conceptual Framework}

Our conceptual framework is guided by the danger of a single story construct, as defined by writer Chimamanda Ngozi Adichie in her 2009 TED Talk. Adichie (2009) stated, "The single story creates stereotypes, and the problem with stereotypes is not that they are untrue, but that they are incomplete. They make one story become the only story." Adichie emphasizes multiple stories, narratives, and truths. Historically, scholarship on Black people in the U.S. education system centers on a "universal Black experience," in which the experiences of this population are combined and compared to Whites (George Mwangi, 2014). This homogenous single story is marginalizing and runs counter to the rhetoric of diversity, inclusion, and multiculturalism presented within the field of education.

While a growing body of literature on Blacks disaggregates data (e.g., research on Black male students), we still see vestiges of the single story present in education research. For example, Black students and their families are consistently portrayed in education research in a manner lacking complexity, whether from a deficit-perspective or a lens viewing this population homogeneously (Freeman, 2005; Harper \& Nichols, 2008; Ladson-Billings, 2007). This single story about Black students can lead to stereotyping and the reification of implicit bias within education practice because it allows the field to misrepresent Black students and their performance (Gershenson, Holt, \& Papageorge, 2016). 
Limited information subsequently constrains educators' understanding of their students, and research demonstrates that what teachers believe about their students can impact student performance (Gershenson et al., 2016). This singularity is also problematic because it communicates to education practitioners that considering the background context and unique needs of students is not important when developing curriculum, interventions, or assessment. Conversely, when data are disaggregated, this presents the diversity within a racial group in order to view how other factors such as socioeconomic status and language proficiency may intersect to impact student outcomes (Blum, 2015). Thus, disaggregated data and research provides an opportunity to more accurately understand Black students' educational experiences and lead to more effective education practices.

Our systematic literature review challenges the single story. We do so by engaging research on the educational experiences of Black immigrants in order to present a holistic understanding of this scholarship. To present this holistic understanding, we analyzed research designs within the published literature as well as themes and patterns within its content. We use the single story construct to investigate whether a single story is present, emphasize the dangers inherent in the single story, and present opportunities for future research that move beyond the single story.

\section{Approach}

Systematic reviews provide a comprehensive and structured mode of inquiry, analyze extant scholarship, identify gaps in the literature, and highlight areas for future research (Bearman et al., 2012). We use a nine stage process for the review: (a) frame questions for review; (b) define inclusion and exclusion criteria; (c) describe the search strategy; (d) screen the literature using inclusion and exclusion criteria; (e) report the results of the search strategy; (f) provide description/relevant characteristics of included studies; (g) assess the methodological rigor of the included studies; (h) summarize evidence of the included studies; and (i) interpret findings and draw conclusions (Gough, 2007). While many models of systematic literature reviews are applied for medical/ health scholarship, we selected this process because Gough (2007) also applies the approach to review social science/education research (Gough, Oliver, \& Thomas, 2012).

\section{Framing Question for Review}

Two questions guide this review:

1. How have education scholars designed research that investigates the educational experiences of Black immigrants? 
2. What key themes are present in contemporary scholarship on the experiences of Black immigrants within the U.S. education system?

These questions allow us to analyze both the research designs and research findings/content within the studies reviewed.

\section{Inclusion-Exclusion Criteria, Search Strategy, and Screening}

We conducted a comprehensive literature search by combing four online bibliographic databases: ERIC, Education Index Retrospective, Education Research Complete (EBSCO), and Google Scholar. The search terms were a combination of Black immigrant, education, high school, middle school, elementary school, higher education, undergraduate, and graduate. We retrieved 3,080 articles, removed 332 duplicates, and ultimately reviewed a total of 2,748 articles using inclusion and exclusion criteria.

The inclusion and exclusion criteria were based on five factors (see Appendix A). We reviewed titles and abstracts to determine whether they were relevant to the inclusion criteria. This led to the exclusion of 2,476 articles while 272 articles proceeded to full-article screening. The majority of these studies were excluded because they did not focus on the topic of interest (e.g., educational experiences, Black immigrants, or U.S. education). For example, approximately one-quarter of the articles that were excluded focused on Black immigrants' U.S. workforce participation, rather than their engagement in the U.S. education system. Approximately one-third of the articles were excluded because of publication type (e.g., was not an empirical study or was a dissertation). Next, we evaluated the 272 full texts to assess if they met the inclusion criteria. An additional 151 texts were excluded after this review. The majority of these were excluded due to study participants (e.g., participants were not Black immigrants or educators working with Black immigrants) or the study focus not on the topic of interest (e.g., U.S. educational context).

\section{Quality Assessment and Sample of Studies}

We chose to include only studies that met a prescribed level of methodological rigor. Thus, we implemented stage seven (assess the methodological rigor of the included studies) prior to stage six (provide description/relevant characteristics of included studies) (Gough, 2007) in order to engage the 121 articles in a quality assessment. We created a research design checklist to ensure that studies included information explaining how data were managed and interpreted in order to select only those works emphasizing systematic and rigorous inquiry. We appraised whether research design choices made within a study aligned with the stated purpose of the study and methodology selected, as well as whether design choices were implemented within the study 
and mechanisms for data quality were addressed. This led to an additional 36 articles being excluded, leaving a total of 85 articles in the dataset (see Appendix B). Twenty-two of these articles were excluded because they did not discuss issues related to how data quality was maintained (e.g., reliability, validity, credibility, trustworthiness). Five articles did not address the limitations of their study. Eight of the articles were presented as empirical articles, but did not describe one or more key components of their research design (e.g., sampling procedures, data analysis process).

\section{Analysis}

We began the analytic process by performing multiple reads of each article to situate and compare them. We summarized each study's research setting, participants, methods, purpose, theoretical/conceptual framework, and key findings (see Appendix C). Next, we engaged in thematic analysis of the literature, which both aggregates and interprets the body of work (Hemsley-Brown \& Oplatka, 2006). The goal of this type of analysis is to "summarize what is known and established already, and focus on the extent to which consensus is shared across various themes," (Hemsley-Brown \& Oplatka, 2006, p. 14). We conducted three forms of analysis. First, we focused on the research designs of the studies, specifically the conceptual/theoretical frameworks and methodology/methods sections of each article. We engaged in an inductive analysis by identifying design choices within the studies and then naming patterns across the studies. For example, within studies' research samples, we used codes such as "Black immigrants only," "Black immigrants and Black Americans," and "Black immigrants and other immigrants." After identifying the sampling design choices, we clustered articles by type of sample in order to document whether there were other themes and patterns present within the cluster of articles. We repeated this process to identify design choices and name patterns within the theoretical/conceptual frameworks and other components of the methods. Major clusters of patterns were found regarding frameworks, sampling procedures, and areas of the education pipeline. Second, we analyzed themes within the research findings. We developed a set of inductive themes based on primary findings related to Black immigrants' educational experiences within the articles such as "role of parents," "role of immigrant identity," and "experiences with stereotyping in school." We reduced our initial list of themes by combining them into three broad categories: (a) role of social structures (b) role of culture and immigrant identity, and (c) Black immigrants' hybrid/bi-cultural identities. Lastly, we utilized our conceptual framework to focus on the development of a synthesized interpretation of the themes, emphasizing a response to our research questions. During this third phase of analysis, we considered whether and how the themes found within the studies' research designs and findings presented a singular narrative about Black immigrants. We present this level of analysis within the Discussion section. Based upon the patterns that emerged from the data during analysis and synthesis, we interpreted how scholars present the U.S. educational experiences of Black immigrants. 


\section{Findings}

Themes are divided into two categories: research design and content patterns. First, there were patterns found among the research designs in the dataset regarding theoretical frameworks, sampling, and areas of emphasis within the educational pipeline. Second, patterns regarding content across the studies emphasized the role of social structures, culture, and hybrid identities.

\section{Research Designs}

Scope of frameworks. Although a range of frameworks was used in many of the studies examining Black immigrants' educational experiences, almost twothirds of the studies included an assimilation or acculturation framework. Seven studies used an assimilation framework (e.g., Perreira, Harris, \& Lee, 2006; Portes \& Schauffler, 1994; Thomas, 2012), eleven used segmented assimilation theory (e.g., De Feyter \& Winsler, 2009; Keller \& Tillman, 2008; Raleigh \& Kao, 2010), and four used an acculturation framework (Doucet, 2005; Fries-Britt, George Mwangi, \& Peralta, 2014a; George Mwangi \& Fries-Britt, 2015; Hersi, 2011). These frameworks were derived from the experiences of European Whites and their socialization patterns (e.g., suppressing native languages and customs) and place an emphasis on immigrants' ability to integrate into American society and achieve social mobility (Rong \& Brown, 2001; Waters, 1994). While assimilation-based frameworks focus on immigrants' strategies for mobility and integration, segmented assimilation or acculturation differs in that immigrants retain elements of their identity and culture as a way to resist some aspects of assimilation and social norms (De Feyter \& Winsler, 2009). For example, Doucet (2005), Raleigh and Kao (2010), and Roopnarine et al. (2006) found that Black immigrant parents' cultural values regarding education (e.g., the teacher is an expert) influenced how they supported and understood their children's educational experiences. Generally, parents who emphasized cultural expectations and educational aspirations were less likely to assimilate, and parents' attitudes likely contributed to their children's academic motivations and success.

While assimilation-based frameworks highlight how immigrants attempt to adjust to a new society and educational system, they are incomplete when Black immigrants' sociocultural background and contexts are not considered. An alternative to assimilation frameworks is Ogbu's (1981) Cultural Ecological Theory (CET), which he later adapted with Simons in 1998. In our review, CET was used in six studies (e.g., Adeniji-Neill, 2011; Fisher, 2005; Gilbert, 2009). CET focuses on the different ways voluntary (e.g., Black immigrants choosing to migrate) and involuntary (e.g., native-born Blacks forced to come to U.S. during slavery) immigrants perceive their treatment and incorporation into U.S. society (Ogbu \& Simons, 1998). In a quantitative analysis testing CET, Jenkins, Harburg, 
Weissberg, and Donnelly (2004) examined the academic performance and persistence of voluntary and involuntary Black college students. Jenkins and colleagues' results support CET in that voluntary immigrants showed differences in persistence compared to involuntary immigrants. Conversely, Gilbert (2009) suggests that socioeconomic status and behavioral characteristics more likely contribute to differences in performance than does immigrant background. These studies illustrate that multiple factors including cultural background, socioeconomic status, and race inform students' approaches toward education (Ogbu \& Simons, 1998). Thus, the use of assimilation frameworks without further consideration of Black immigrants' sociocultural contexts paints an incomplete picture of their education experiences.

Analysis of research samples. There were two types of sampling designs: studies in which Black immigrants were a component of a larger sample of other student populations and studies that focused solely on Black immigrants. Forty articles were comparison samples, with 19 studies comparing Black immigrants to native-born Blacks, and five comparing Black immigrants to other immigrant groups. All other studies compared across both race and immigrant generation/nativity (whether or not the student was born in the U.S.) in their samples.

The inconsistency in comparison samples raised several questions. Who should be the comparison group to Black immigrants? Does focusing on shared race or shared nativity within a sample provide a more effective means of understanding Black immigrant students' experiences? Articles comparing Black immigrants to native-born Blacks argue that this is effective for understanding the impact of nativity/ethnicity/cultural/historical contexts on the educational experiences of Black students (e.g., Calzada et al., 2015; Foster, 2005; Haynie, 2002; Massey et al., 2007; Tauriac \& Liem, 2012); for demonstrating the withingroup diversity that exists among Black students (e.g., Byrd, Brunn-Bevel, \& Sexton, 2014; Traoré, 2004; Williamson, 2010); or for understanding how racial identity is constructed and experienced among diverse Black students (e.g., Anglin \& Wade, 2007; Thomas, Howard Caldwell, Faison, \& Jackson 2009). The central emphasis of these studies is Black heterogeneity. Conversely, articles comparing Black immigrants to other immigrants focus on the impact of assimilation patterns on student achievement (Carhill, Suárez-Orozco, \& Páez, 2008; Conger, Schwartz, Stiefel, 2011; Rumbaut, 1994); the impact of race on student achievement (Thomas, 2012); and discrimination in the student experience (Lee \& Rice, 2007).

Comparing across both race and nativity may offer comprehensive sampling. However, these studies typically used data from large national databases in which the number of Black immigrants is often the smallest in the sample. For example, Raleigh and Kao's (2010) study used data from the Early Childhood Longitudinal Study-Kindergarten Cohort, and Peguero, Shekarkhar, Popp, and Koo's (2015) study used data from the Education Longitudinal Study. Many of these articles do not target the experiences of Black immigrants, but instead make more general comparisons across students by nativity/generation 
status and race. Thus, the particularities of Black immigrants' experiences are not emphasized as they are in Perreira et al.'s (2006) study that samples the first generation youth of African heritage along with native-born Blacks and Hispanic and Asian immigrants and native youth.

Additionally, studies that compare different student populations across race and/or nativity often aggregate Black immigrants as if they are monolithic. This includes combining all African, Caribbean, and Latin American Black immigrants as a singular group within a sample (e.g., Barnett, Sonnet, \& Sadler, 2012; Calzada et al., 2015; Glick \& Hohmann-Marriott, 2007). Yet, there is incredible diversity among Black immigrants from these origins, and aggregating may mask this.

Over half of the studies in this sample do not compare Black immigrants with other student populations. These studies either focus on Black immigrants broadly, such cas the study of Black immigrant collegians by Griffin and Mclntosh (2015); on one region from which Black immigrants originate, such as Hailu and Ku's (2014) study of African students; or on one specific nationality of Black immigrants, such as Doucet's (2005) study of Haitian youth. Of studies focused on samples by region, 20 included immigrants from the Caribbean/Latin America, while 19 focused on immigrants from Africa. In nationality-specific samples, immigrant home countries included Haiti, Nigeria, Ghana, Trinidad and Tobago, Somalia, Cape Verde, Ethiopia, Sudan, and Kenya. Studies with disaggregated data were often based on qualitative samples (ranging from samples of one to samples of 150 participants, with an average of 26 participants). Only nine of the disaggregated studies were quantitative, and only one was mixed methods.

The educational pipeline. The studies span the education pipeline from pre-kindergarten to post-college, with particular emphasis on high school and college experiences. Black immigrant students' xperiences in elementary, middle, and graduate schools are understudied. Only two studies specifically targeted middle school, while 15 were a combination of middle school with elementary and/or high school. Eight studies explored elementary school (generally prekindergarten to 4th grade) experiences and performance. In the studies of lower levels of education, Black immigrants were often collapsed as one group regardless of generation or nationality differences. These studies suggest that Black immigrants likely possess an immigrant advantage based on early performances in the early years compared to native-born Black and Latino peers (Calzada et al., 2015; De Feyter \& Winsler, 2009; Glick \& Hohmann-Marriott, 2007). Researchers often attribute culture as a factor in performance.

Of the 20 articles focused on high school students, the primary analysis was academic performance and achievement (e.g., Hersi, 2011; Njue \& Retish, 2010), followed by identity (e.g., Coutinho \& Koinis-Mitchell, 2014; McLean, 2010). In terms of Black immigrants' experiences between high school and college, there is an emphasis on how cultural differences inform academic achievement and college enrollment (e.g., Bennett \& Lutz, 2009; Byrd et al., 2014; Hagy \& Staniec, 2002; Massey et al., 2007; Warikoo, 2004). Several scholars point to issues of stereotypes (Traoré, 2004), economic hardships (Calzada et al., 2015), teacher expectations (Burrell et al., 2015), migration transitions (Mugisha, 2015), and 
language adaptations (Portes \& Schauffler, 1994) that Black immigrant students encounter, which may be sources of motivation to succeed. However, these factors may also negatively impact their success and self-perceptions (Fisher, 2005; Mugisha, 2015).

Most of the scholarship on Black immigrants' postsecondary experiences was published within the last 12 years. Thirty-two studies examining collegiate experiences generally involve racial identity and socialization, and their influence on academic performance, enrollment, or cultural adjustment to college (e.g., Anglin \& Wade, 2007; Constantine, Anderson, Berkel, Caldwell, \& Utsey., 2005; Sanchez, 2013). These studies point to the theme of Black immigrants' overrepresentation, particularly at selective institutions, and their academic performance in comparison to native-born Blacks.

\section{Content Patterns}

Emphasis on social structures. A major pattern emerging from the literature emphasized how social structures shape the educational experiences and outcomes of Black immigrants. Social structural factors impacting the educational experiences of Black immigrants include legal or economic factors, schooling structures, and social networks. Privileged class, educational backgrounds, and human capital contribute to migrant selectivity influencing who migrates to the United States and, in particular, to the academic achievement experienced by some Black immigrants. For example, research on Black refugees and asylees in the U.S. demonstrates that they are positioned as less likely to succeed academically due in part to structural factors such as limited levels of human capital, interrupted schooling experiences, and under-resourced schools (Fawzi et al., 2009; Kia-Keating \& Ellis, 2007; Mugisha, 2015; Roxas \& Roy, 2012).

Social structures are also found to positively impact the educational experiences of Black immigrants. Massey et al. (2007) found that the most critical difference between Black immigrant and Black native-born students attending selective colleges and universities indicates that Black immigrants were more likely to come from two-parent households and to have fathers who graduated from college and hold advanced degrees. Like Massey et al. (2007), Bennett and Lutz (2009) found that Black immigrants were more likely to come from two-parent households and attend private $\mathrm{K}-12$ schools. When the researchers controlled for social and economic backgrounds, the college-going gap between Black immigrant and native-born students was significantly reduced. Thus, Bennett and Lutz (2009) concluded that structural resources rather than cultural differences were most impactful in these students' college going behaviors. Overall, 21 articles (e.g., Knight, Roegman, \& Edstrom, 2015; Lee \& Kao, 2009; Rong \& Brown, 2001; Thomas, 2009; Thomas, 2012) demonstrate that Black immigrants' positioning in the social class system, labor market, and racial structure of American society can create accessibility or barriers to their educational and occupational attainment. 
Additionally, six articles explicitly argue an inability to separate the racial system and structures of oppression in U.S. society from the educational experiences and achievement of Black immigrants (Albertini, 2004; Charles, Kramer, Torres, \& Brunn-Bevel, 2015; Constantine et al., 2005; Knight et al., 2015; Peguero et al., 2015; Rong \& Brown, 2001). Knight et al. (2015) used structuration theory and agency to illustrate how over time Black immigrants' desire to attain the "American Dream" through education was challenged and constrained by racist and classist systems in the United States. Racial mistrust, racial classification, racial prejudice/ discrimination, dominant racial narratives, and racial disparities in school discipline among these studies were found to play a role in how Black immigrants were treated in their schools and the impact on their academic success.

Emphasis on culture and immigrant identity. Another theme in this scholarship affirms that culture shapes the educational experiences and outcomes of Black immigrants. Some researchers argue that Black immigrants' cultural response to racism and oppression in the U.S. helps foster educational and occupational success. Waters (1994) and Rumbaut (1994) conducted studies with Black immigrant youth, asserting that youth's self-identification is correlated with their patterns of assimilation and/or cultural responses to racism. Waters (1994) posits that youth who identify as Black/African American often experienced greater downward assimilation because of internalized racism and prejudicial treatment of Blacks. She concluded that youth who identified as West Indian exuded more effort and initiative in schooling because they did not perceive a high level of racial limitation (Waters, 1994).

Conversely, Awokoya (2012) and Cone, Buxton, Lee, and Mahotiere (2014) found negative implications of ethnic and cultural markers on the educational experiences of Black immigrant youth. In Awokoya's (2012) study of Nigerian 1.5(migrated before age 12) and second-generation students, participants encountered a number of negative stereotypes from teachers and peers about their intelligence, academic abilities, and African heritage. Like social structural factors, culture and cultural identity can have both positive and negative implications for Black immigrants' educational experiences and outcomes. Because a number of authors found that culture had a strong impact on Black immigrants' educational experiences, they argued for teachers to receive professional development regarding the cultures of Black immigrant students, as well as for the use of culturally-relevant pedagogies (e.g., Allen, Jackson, \& Knight, 2012; Awokoya, 2012; Okpalaoka \& Dillard, 2012; Sanchez, 2013; Washington Cherry, 2015).

Culture and immigrant identity were discussed as protective factors in 16 articles (e.g., Barnett et al., 2012; Coutinho \& Blustein, 2014). Haynie (2002) found that Black immigrant students were more likely to strive to attend Harvard due to their families' legacy of immigration and the importance of taking advantage of opportunities in the United States. Like Haynie (2002), Griffin, del Pilar, McIntosh, and Griffin (2012) found that "culture, prestige, and the value parents place on education" (p. 96) were primary factors influencing the college choice of Black 
immigrants. The researchers argue that these messages helped students develop a habitus or worldview that emphasized the importance of attaining a college education as part of their cultural legacy. Students described the value of education, the discipline required to achieve academically, and the goal to attend college as cultural norms embedded in their ethnic identities (Griffin et al., 2012).

Although structural and cultural factors are discussed separately in this review, they are not mutually exclusive. Most studies discussed both themes, and 15 of the articles specifically emphasized the interplay between the culture/nativity of Black immigrants and the social structures that impact their educational experiences (e.g., Alfred, 2003; Conger et al., 2011; Fisher, 2005; Fries-Britt et al., 2014b; George Mwangi \& Fries-Britt, 2015; Njue \& Retish, 2010). By engaging both factors, authors often demonstrate how Black immigrants are able to use culture as a motivating force to overcome structural barriers in the education context.

Bi-cultural identity. The final pattern identified was the development of a hybrid or bicultural identity within educational contexts. A hybrid identity was due to Black immigrants' complex navigation of both familial and American/peer cultural norms, thus reflecting an on-going identity process (Allen et al., 2012; Cone et al., 2014; De Walt, 2011; Doucet, 2005; Rumbaut, 1994; Waters, 1994). Of the 19 studies focused on identity, 16 addressed some form of a hybrid identity. In some instances this "dual identity" was referred to as bicultural (Coutinho \& Koinis-Mitchell, 2014; Doucet, 2005) or fluid (Rivers, 2012).

Several scholars cited the seminal work of Waters (1994) who found that the West Indian youth in her study ascribed to three identities: American, ethnic/hyphenated, or immigrant. Awokoya (2012), De Walt (2011), Joseph and Hunter (2011), Rivers (2012), and Rumbaut (1994) found similar identifications among their African and Caribbean participants. Black immigrants seem to develop a hybrid identity in which they attempt to bridge two cultures (the United States and their home country/parents' home country). School was the primary site where this bridging occurred. Feliciano (2009) is one of the few longitudinal studies that point to the shifting of participants' ethnic identifications between adolescence and early adulthood, stressing the importance of tertiary educational influences and time on ethnic identity development.

Scholars also found several factors such as gender, SES, racial/ethnic composition of neighborhood/school, language, generation status, nativity, and family to strongly influence the racial/ethnic identifications of Black immigrants (e.g., Cone et al., 2014; Fries-Britt et al., 2014b; Rivers 2012). Awokoya (2012) and McLean (2010) added social media and online communication to these factors. These findings point to the need to better understand the formation and conditions of hybrid identities.

Viewing identity construction as fluid and bidirectional given the unique combination of homeland and U.S. contexts of Black immigrants helps to challenge monolithic understandings of Black identity. Further, a "binational," "panethnic," or hyphenated identity among Black immigrant youth points to generational 
differences in self-identifications (Keller \& Tillman, 2008; Rumbaut, 1994), whereby children of immigrants are more likely to adopt a hybrid identity. This is likely associated with their longer period of time spent in the United States (Waters, 1994). Lastly, the various factors that contribute to a hybrid identity affirm the powerful context of the U.S. education system, which may sometimes contradict home values and position students in a cultural bind (Allen et al., 2012; Doucet, 2005).

\section{Discussion}

Our findings reveal that the presentation of Black immigrants within the growing body of education literature is incomplete in terms of the theories and sampling parameters used to examine their experiences. The results of this analysis point to a larger issue wherein the prevailing theme across the studies reflects a single narrative concerning this group.

The wide use of assimilation and acculturative frameworks in the study of Black immigrants places a particular emphasis on students' immigrant status and outcomes related to their ability to integrate into the American education system. These frameworks were often applied without full consideration of the sociocultural background and context of Black immigrants. The use of such frameworks in isolation purports the widely held belief in the immigrant advantage and model minority myth. Because acculturative frameworks generally highlight immigrant status, these frameworks cast a shadow on the barriers that the U.S. racial hierarchy poses, which many Black immigrants must navigate. This leaves minimal room for considering and understanding the multiple experiences that exist among Black immigrants and the diverse ways in which many factors such as class and race influence how they navigate their education. Black immigrants not only contend with the racial hierarchy but also with socio-economic, social, and political challenges that can lead to downward mobility, discrimination, and oppression (Rong \& Brown, 2002).

The sampling methods used in many of the studies reflected the heterogeneity within the Black community but were still limited in terms of comparison groups and disaggregation of data. Black immigrants were commonly aggregated into a broad immigrant group in comparison studies or studied solely by region. Yet, there is considerable diversity among Black immigrants especially by country (e.g., Nigeria, Jamaica). Groups are also different in terms of socioeconomic status, mode of entry into the United States (voluntary vs. refugee/asylee), English language ability, and previous educational experiences (Anderson, 2015; Kent, 2007). Education literature demonstrates that these characteristics can impact how immigrants engage in the U.S. education system (Baum \& Flores, 2011; Portes \& Fernandez-Kelly, 2008).

Most studies address high school and college experiences, leaving elementary, middle, and graduate school experiences understudied. Black 
immigrants appear to excel throughout their educational journeys, yet little is known about what occurs in their formative and later years of schooling. An understanding of Black immigrants' formative and later years in education may provide a more comprehensive understanding of their overall experiences, which can help to problematize the new model minority myth and the singular story regarding their achievement.

This singular story is further portrayed in patterns across studies. The role of social structures and bicultural identity points to culture as an intermediary, whereby Black immigrants employ their culture as a protective factor against social, political, and economic barriers that ultimately aid in their educational success (Barnett et al., 2012; Massey et al., 2007). In the aggregate, the single story of Black immigrants as a group, whose adaptation is segmented, academically astute, and culturally similar, is a broad brush stroke and covers up the cultural, historical, and social contexts these groups must navigate. Whereas Black immigrants have some similarities across identity and experience, the literature fails to fully capture the influence of socio-historical norms, shared meanings, and individual perspective that are relative to context. Furthermore, each group arrives to the United States with different resources (e.g., economic background, education, and social networks) and engages diverse educational pathways.

A single story also emerges in the comparison of Black immigrants to native-born Black Americans. Due to the highly racialized nature of U.S. society and the racial stratification often present in educational outcomes (George Mwangi, 2014; Bartlett \& Brayboy, 2005; Ladson-Billings \& Tate, 1995), this comparison addresses the intersection of racial minority status with nativity/ethnicity and its impact on educational experiences. Nearly a quarter of the studies compare Black immigrants' educational outcomes to those of native-born Black Americans. While this comparison can be useful in considering intra-group diversity among Black students, it can also be framed or perceived in ways that create a divisive tone, positioning Black immigrants as a superior group to nativeBlacks or as a population without challenges in the education system.

For example, some scholars emphasize culture and familial expectations as a promoter of academic success (e.g., Barnett et al., 2012; Haynie, 2002). These factors may play a role, but if findings are not unpacked within the sociohistorical context of U.S. society and education, it can perpetuate the trope of Black immigrants as the "new model minority" based on scholastic and economic success. This image is problematic, since early research used comparisons of Black immigrants to native-born Black Americans to validate arguments that race and racism are insufficient factors for explaining lower levels of Black native-born performance (Glazer \& Moynihan, 1963; Sowell, 1978). Instead, authors stated that cultural deficiencies and inability to assimilate to the dominant (White) culture accounted for these differences (Glazer \& Moynihan, 1963; Sowell, 1978). While early research is largely discredited today, frameworks and concepts such as immigrant exceptionalism, cultural ecology theory, assimilation/acculturation, and the immigrant advantage paradox can appear reminiscent of this perspective and 
oversimplify the educational experiences of both Black immigrants and Black native-born. The experiences of Black immigrants are relative to context and situated within the racial, cultural, political, and socio-historical structures of the United States, which position them in both similar and different ways from Black Americans. Without acknowledging this context, education research can reify the single story narrative of Black immigrants and Black Americans.

However, we do not argue that comparing the experiences of Black immigrants and Black native-born students is inherently divisive. In fact, we believe comparing the two groups can be useful in creating supports for their similar and unique needs. Scholars can draw comparisons in a way that intentionally counters a divisive, single story narrative, such as Washington Cherry's (2015) study that used the framework of diaspora to understand intra-group engagement among Blacks of different ethnicities in schools and contextualized their interactions within broader racialization processes in U.S. society. Other scholars also drew connections to the social positioning of Black immigrants and Black Americans, rather than engaging deficit narratives about Black Americans (e.g., Charles et al., 2015; Haynie, 2002; Traoré, 2004). This type of analysis can center socio-historical and systemic issues in U.S. society and abroad, which impact the two groups' educational experiences, placing greater onus on improving the educational policies and practices affecting students' performance rather than focusing on one group's performance over the other.

\section{Implications}

Methodologically, while the number of qualitative and quantitative studies was almost equal, we found few studies using mixed methods approaches. Yet, in reviewing the sampling design of the dataset of articles, we see greater need for mixed methods studies. A number of existing quantitative studies used national datasets with low representation of Black immigrant participants, whereas the qualitative studies lacked generalizability due to small samples. By using mixed methods, researchers can offset the limitations of quantitative and qualitative methods and provide greater completeness (Bryman, 2006). By using both methods, the research will provide a more comprehensive account of Black immigrants' educational experiences than if only one were used.

More data on this population are needed to understand their backgrounds, educational expectations, and needs. Many researchers will continue to struggle with the limited data due to the ways in which demographic data are collected in the United States. For example, the federal government's education databases do not disaggregate data by both race and citizenship. Additionally, many universities only maintain data on the birthplace of their students, but not of students' parents, which does not allow for second-generation Black immigrants to be acknowledged as such because they are subsumed into the U.S.-born/African American population. Demographic data collection and reporting need to keep pace with the diverse nativity, ethnicities, and nationalities of Blacks in the United States as a 
means of making research on the educational experiences of Black immigrants more feasible.

Future research should focus more on the early years of schooling such as pre-K to 8th grade as well as post college/graduate experiences. Very little is known about the early education experiences of Black immigrants that help to inform their latter years in education. An investigation of the early and later parts of Black immigrants' educational experiences can provide a more well-rounded picture of how they engage in different parts of the education pipeline, where they may experience challenges, and the types of support they need at all levels.

A theoretical implication is the scope of frameworks used within the studies. Most studies utilized assimilation or acculturative frameworks, leaving an incomplete picture in how this group is presented. Although assimilation and cultural ecological frameworks help to identify the strengths Black immigrants draw from their culture, their over-utilization may limit understandings of Black immigrants and lead to a consistent view of Black immigrants with a "distinct advantage" over other non-immigrants, and some immigrant groups (Bennett \& Lutz, 2009; Calzada et al., 2015; De Feyter \& Winsler, 2009), while masking the challenges they experience in the education context.

It is important that future research highlights dynamics that impact the worldviews and educational experiences of Black immigrants and integrate sociohistoric, political, and cultural factors that influence how they navigate U.S. education. Engaging critical, culturally sustaining, and/or constructivist frameworks will produce research that presents a more holistic view of this group. Most of the current articles using these frameworks were written within the past five years, demonstrating this as a growing approach. Another potential framework is diasporic consciousness, a lens emphasizing how relationships are formed or strained based on a shared diasporic connection embedded in issues of power, oppression, migration, and culture (Vertovec, 1999a, 1999b). Frameworks such as this can be useful in elucidating the divisive dialogue and positioning of native and immigrant Blacks.

Researchers should also explore the conditions in which hybrid identities develop and how best to support students through this process. A major factor contributing to Black immigrants' complex negotiation of a hybrid identity is how they were racialized by peers and teachers, as well as cultural expectations from family (Awokoya, 2012; Doucet, 2005; Feliciano, 2009; Joseph \& Hunter, 2011). Having the knowledge of a hybrid identity underscores the need for culturally relevant practices that account for the variability in students' cultural backgrounds and ideologies (Cone et al., 2014). Such practices can create viable relationships between home and school expectations and practices. Moreover, hybrid identities challenge the fixed discourse around race and can inform relevant approaches to research that intentionally incorporates various ethnicities and nationalities within the African diaspora (Allen et al., 2012; Hernandez \& Murray-Johnson, 2015). By expanding the use and diversity of frameworks, researchers can begin to view Black immigrants from a number of perspectives that help to further the awareness 
and understanding of the heterogeneity that exists among the Black community in the United States.

\section{References}

Adeniji-Neill, D. (2011). Omolúàbí: The way of human being: An African philosophy's impact on Nigerian voluntary immigrants' educational and other life aspirations. Irinkerindo: A journal of African migration, 5, 1-28.

Adichie, C. (2009). The danger of a single story. [Video file]. Retrieved from: https://www.ted.com/talks/chimamanda_adichie_the_danger_of_a_single_ story?language $=e n$

Albertini, V. L. (2004). Racial mistrust among immigrant minority students. Child and Adolescent Social Work Journal, 21(4), 311-331.

Alfred, M. V. (2014). Sociocultural contexts and learning: Anglophone Caribbean immigrant women in U.S. postsecondary education. Adult Education Quarterly, 53(4), 242-260.

Allen, K. M., Jackson, I., \& Knight, M. G. (2012). Complicating culturally relevant pedagogy: Unpacking West African immigrants' cultural identities. International Journal of Multicultural Education, 14(2), 1-28.

Anderson, M. (2015). A rising share of the U.S. Black population is foreign born; 9 percent are immigrants; and while most are from the Caribbean, Africans drive recent growth. Washington, DC: Pew Research Center.

Anglin, D. M., \& Wade, J. C. (2007). Racial socialization, racial identity, and Black students' adjustment. Cultural Diversity and Ethnic Minority Psychology, 13(3), 207-215.

Awokoya, J. T. (2012). Identity constructions and negotiations among 1.5- and second-generation Nigerians: The impact of family, school, and peer contexts. Harvard Educational Review, 82(2), 255-281.

Barnett, M. D., Sonnert, G., \& Sadler, P. M. (2012). More like us: The effect of immigrant generation on college success in mathematics. International Migration Review, 46(4), 891-918.

Bartlett, L., \& Brayboy, B. (2005). Race and schooling ethnographies: Directions for the future. The Urban Review, 37(5), 361-374.

Baum, S., \& Flores, S. M. (2011). Higher education and children in immigrant families. The Future of Children 21(1), 171-193.

Bearman, M., Smith, C. D., Carbone, A., Slade, S., Baik, C., Hughes-Warrington, M., \& Neumann, D. L. (2012). Systematic review methodology in higher education. Higher Education Research and Development, 31(5), 625-640. 
Bennett, P. R., \& Lutz, A. (2009). How African American is the net Black advantage? Differences in college attendance among immigrant Blacks, native Blacks, and Whites. Sociology of Education, 82, 70-100.

Blum, L. (2015). Race and class categories and subcategories in educational thought and research. Theory and Research in Education, 13(1), 87-104.

Bryman, A. (2006). Integrating quantitative and qualitative research: How is it done? Qualitative Research, 6, 97-113.

Burrell, J. O., Fleming, L., Fredericks, A. C., Moore, I. (2015). Domestic and international student matters: The college experiences of Black males majoring in engineering at an HBCU. The Journal of Negro Education, 84(1), 40-55.

Byrd, W. C., Brunn-Bevel, R. J., \& Sexton, P. R. (2014). 'We don't all look alike:' The academic performance of Black student populations at elite colleges. Du Bois Review, 11(2), 353-385.

Calzada, E., Barajas-Gonzalez, R. G., Dawson-McClure, S., Huang, K. Y., Palamar, J., Kamboukos, D., \& Brotman, L. M. (2015). Early academic achievement among American low-income Black students from immigrant and non-immigrant families. Prevention Science, 16(8), 1159-1168.

Carhill, A., Suarez-Orozco, C., \& Paez, M. (2008). Explaining English language proficiency among adolescent immigrant students. American Educational Research Journal, 45(4), 1155-1179.

Charles, C. Z., Kramer, R. A., Torres, K. C., \& Brunn-Bevel, R. J. (2015). Intragroup heterogeneity and Blackness: Effects of racial classification, immigrant origins, social class, and social context on the racial identity of elite college students. Race and Social Problems, 7(4), 281-299.

Cone, N., Buxton, C., Lee, O., \& Mahotiere, M. (2014). Negotiating a sense of identity in a foreign land: Navigating public school structures and practices that often conflict with Haitian culture and values. Urban Education, 49(3), 263-296.

Conger, D., Schwartz, A. E., \& Stiefel, L. (2011). The effect of immigrant communities on foreign-born student achievement. International Migration Review, 45(3), 675-701.

Constantine, M. G., Anderson, G. M., Berkel, L. A., Caldwell, L. D., \& Utsey, S. O. (2005). Examining the cultural adjustment experiences of African international college students: A qualitative analysis. Journal of Counseling Psychology, 52(1), 57-66.

Coutinho, M. T., \& Blustein, D. L. (2014). Cape Verdean immigrants' career development and school engagement: Perceived discrimination as a moderator. Journal of Career Development, 41(4), 341-358.

Coutinho, M. T., \& Koinis-Mitchell, D. (2014). Black immigrants and school engagement: Perceptions of discrimination, ethnic identity, and American identity. Journal of Black Psychology, 40(6), 520-538. 
De Feyter, J. J., \& Winsler, A. (2009). The early developmental competencies and school readiness of low-income, immigrant children: Influences of generation, race/ethnicity, and national origins. Early Childhood Research Quarterly, 24, 411-431.

De Walt, P. S. (2011). In search of an authentic African American and/or Black identity: Perspectives of first generation U.S.-born Africans attending a predominantly white institution. Journal of Black Studies, 42(3), 479-503.

Doucet, F. (2005). Divergent realities: The home and school lives of Haitian immigrant youth. Journal of Youth Ministry, 3(2), 37-65.

Fawzi, M. C. S., Betancourt, T. S., Marcelin, L., Klopner, M., Munir, K., Muriel, A. C.,...Mukherjee, J. S. (2009). Depression and post-traumatic stress disorder among Haitian immigrant students: Implications for access to mental health services and educational programming. BMC Public Health, 9(482), 1-11.

Feliciano, C. (2009). Education and ethnic identity formation among children of Latin American and Caribbean immigrants. Sociological Perspectives, 52(2), 135-158.

Fisher, E. J. (2005). Black student achievement and the oppositional culture model. The Journal of Negro Education, 74(3), 201-209.

Foster, K. M. (2005). Gods or vermin: Alternative readings of the African American experience among African and African American college students. Transforming Anthropology, 13(1), 34-47.

Freeman, K. (2005) African Americans and college choice. Albany, NY: State University of New York Press.

Fries-Britt, S., George Mwangi, C. A., \& Peralta, A. M. (2014a). The acculturation experiences of foreign-born students of color in physics. Journal of Student Affairs Research and Practice, 51(4), 459-471.

Fries-Britt, S., George Mwangi, C. A., \& Peralta, A. M. (2014b). Learning race in a U.S. context: An emergent framework on the perceptions of race among foreign-born students of color. Journal of Diversity in Higher Education, 7(1), $1-13$.

George Mwangi, C. A. (2014). Complicating Blackness: Black immigrants \& racial positioning in U.S. higher education. Journal of Critical Thought and Praxis, 3(2), 1-27

George Mwangi, C. A., \& Fries-Britt, S. (2015) Black within Black: The perceptions of Black immigrant collegians and their U.S. college experience. About Campus, 20(2), 16-23.

Gershenson, S., Holt, S. B., \& Papageorge, N. (2016). Who believes in me? The effect of student-teacher demographic match on teacher expectations. Economics of Education Review, 52, 209-224. 
Gilbert, S. (2009). A study of Ogbu and Simons' thesis regarding Black children's immigrant and non-immigrant status and school achievement. The Negro Educational Review, 60(1-4), 71-91.

Glazer, N. \& Moynihan, D. (1963). Beyond the melting pot: The Negros, Puerto Ricans, Jews, Italians, and Irish of New York City. Cambridge, MA: M.I.T. Press.

Glick, J. E., \& Hohmann-Marriott, B. (2007). Academic performance of young children in immigrant families: The significance of race, ethnicity, and national origins. International Migration Review, 41(2), 371-402.

Gough, D. (2007). Weight of evidence: A framework for the appraisal of the quality and relevance of evidence. Research Papers in Education, 22, 213-228.

Gough, D., Oliver, S., \& Thomas, J. (2012) An introduction to systematic reviews. London, United Kingdom: Sage.

Griffin, K., del Pilar, W., McIntosh, K., \& Griffin, A. (2012). “Oh, of course I'm going to go to college": Understanding how habitus shapes the college choice process of Black immigrant students. Journal of Diversity in Higher Education, 5(2), 96-111.

Griffin, K., \& McIntosh, K. L. (2015). Finding a fit: Understanding Black immigrant students' engagement in campus activities. Journal of College Student Development, 56(3), 243-260.

Hagy, A. P., \& Staniec, J. (2002). Immigrant status, race, and institutional choice in higher education. Economics of Education Review, 21(4), 381-392.

Hailu, T. E., \& Ku, H. Y. (2014). The adaptation of the horn of Africa immigrant students in higher education. The Qualitative Report, 19(28), 1-19.

Harper, S. R., \& Nichols, A. H. (2008). Are they not all the same? Racial heterogeneity among Black male undergraduates. Journal of College Student Development, 49(3), 247-269.

Haynie, A. C. (2002). Not 'just Black' policy considerations: The influence of ethnicity on pathways to academic success amongst Black undergraduates at Harvard University. Journal of Public and International Affairs, 13, 40-62.

Hemsley-Brown J., \& Oplatka I. (2006) Universities in a competitive global marketplace: A systematic review of the literature on higher education marketing. International Journal of Public Sector Management, 19(4), 316338.

Hernandez, D. J. (2012). Changing demography and circumstances for young Black children in African and Caribbean families. Washington DC: Migration Policy Institute.

Hernandez, K. A. C., \& Murray-Johnson, K. K. (2015). Towards a different construction of blackness: Black immigrant scholars on racial identity development in the United States. International Journal of Multicultural Education, 17(2), 53-72. 
Hersi, A. A. (2011) Immigration and resiliency: Unpacking the experiences of high school students from Cape Verde and Ethiopia. Intercultural Education, 22(3), 189-202.

Jenkins, A., Harburg, E., Weissberg, N. C., \& Donnelly, T. (2004). The influence of minority group cultural models on persistence in college. Journal of Negro Education, 73, 69-80.

Joseph, N. \& Hunter, C. D. (2011). Ethnic-racial socialization messages in the identity development of second-generation Haitians. Journal of Adolescent Research, 26(3), 344-380.

Keller, U., \& Tillman, K. H. (2008). Post-secondary educational attainment of immigrant and native youth. Social Forces, 87(1), 121-152.

Kent, M. M. (2007). Immigration and America's Black population. Population Bulletin, 62(4), 3-16.

Kia-Keating, M., \& Ellis, B. H. (2007). Belonging and connection to school in resettlement: Young refugees, school belonging, and psychosocial adjustment. Clinical Child Psychology and Psychiatry, 12(1), 29-43.

Knight, M. G., Roegman, R., \& Edstrom, L. (2015). My American dream: The interplay between structure and agency in West African immigrants' educational experiences in the United States. Education and Urban Society, 1-25.

Ladson-Billings, G. (2007). Pushing past the achievement gap: An essay on the language of deficit. Journal of Negro Education, 76(3), 316-323.

Ladson-Billings, G., \& Tate, W. F. (1995). Toward a critical race theory of education. Teachers College Record, 97, 47-68.

Lee, E. M., \& Kao, G. (2009). Less bang for the buck? Cultural capital and immigrant status effects on kindergarten academic outcomes. Poetics, 37, 201-226.

Lee, J. J., \& Rice, C., (2007) Welcome to America? International student perceptions of discrimination. Higher Education, 53(3), 381-409.

Massey, D. S., Mooney, M., Torres, K. C., \& Charles, C. Z. (2007). Black immigrants and Black natives attending selective colleges and universities in the United States. American Journal of Education, 113(2), 243-271.

McLean, C. A. (2010). A space called home: An immigrant adolescent's digital literacy practices. Journal of Adolescent \& Adult Literacy, 54(1), 13-22.

Mugisha, V. M. (2015). Engaged African refugee youth negotiating schooling in America: An inquiry into the influence of culture and social structure. International Journal of Education, 7(1), 165-194.

Njue, J., \& Retish, P. (2010). Transitioning academic and social performance of African immigrant students in an American high school. Urban Education, 45(3), 347-370. 
Ogbu, J. U. (1981). Origins of human competence: A cultural-ecological perspective. Child Development, 52, 413-429.

Ogbu, J. U., \& Simons, H. D. (1998). Voluntary and involuntary minorities: A cultural-ecological theory of school performance with some implications for education. Anthropology and Education Quarterly, 29(2), 155-188.

Okpalaoka, C. L., \& Dillard, C. B. (2012). (Im)migrations, relations, and identities of African peoples: Toward an endarkened transnational feminist praxis in education. Educational Foundations, 26(1-2), 121-142.

Peguero, A. A., Shekarkhar, Z., Popp, A. M., \& Koo, D. J. (2015). Punishing the children of immigrants: Race, ethnicity, generational status, student misbehavior, and school discipline, Journal of Immigrant \& Refugee Studies, 13(2), 200-220.

Perreira, K. M., Harris, K. M., \& Lee, D. (2006). Making it in America: High school completion by immigrant and native youth. Demography, 43(3), 511-536.

Portes, A., \& Fernandez-Kelly, P. (2008). No margin for error: Educational and occupational achievement among disadvantaged children of immigrants. The ANNALS of the American Academy of Political and Social Science, 620(1), 12-36.

Portes, A., \& Schauffler, R. (1994). Language and the second generation: Bilingualism yesterday and today. The International Migration Review, 28(4), 640-661.

Raleigh, E., \& Kao, G. (2010). Do immigrant minority parents have more consistent college aspirations for their children? Social Science Quarterly, 91(4), 10831102.

Rivers, N. M. (2012). No longer sojourners: The complexities racial ethnic identity, gender, and generational outcomes for sub-Saharan Africans in the USA. International Journal of Population Research, 2012, 1-14.

Rong, X. L., \& Brown, F. (2001). The effects of immigrant generation and ethnicity on educational attainment among young African and Caribbean Blacks in the United States. Harvard Educational Review, 71(3), 536-565.

Rong, X. L., \& Brown, F. (2002). Socialization, culture, and identities of Black immigrant children: What educators need to know and do. Education and Urban Society, 34(2), 247-273.

Roopnarine, J. L., Krishnakumar, A., Metindogan, A., \& Evans, M. (2006). Links between parenting styles, parent-child academic interaction, parent-school interaction, and early academic skills and social behaviors in young children of English-speaking Caribbean immigrants. Early Childhood Research Quarterly, 21, 238-252.

Roxas, K., \& Roy, L. (2012). "That's how we roll:" A case study of a recently arrived refugee student in an urban high school. Urban Review, 44, 468-486. 
Rumbaut, R. G. (1994). The crucible within: Ethnic identity, self-esteem, and segmented assimilation among children of immigrants. International Migration Review, 28(4), 748-794.

Sanchez, D. (2013). Racial and ego identity in Black Caribbean college students. Journal of Diversity in Higher Education, 6(2), 115-126.

Sowell, T. (1978). Three Black histories. In T. Sowell (Ed.), Essays and data on American ethnic groups (pp. 7-64). Washington, DC: The Urban Institute.

Tauriac, J. J., \& Liem, J. H. (2012). Exploring the divergent academic outcomes of immigrant-origin Black undergraduates. Journal of Diversity in Higher Education, 5(4), 244-258.

Thomas, K. J. A. (2009). Parental characteristics and the schooling progress of the children of immigrant and U.S.-born Blacks. Demography, 46(3), 513-534.

Thomas, K. J. A. (2012). Migration processes, familial characteristics, and schooling dropout among Black youths. Demography, 49(2), 477-498.

Thomas, O. N., Howard Caldwell, C., Faison, N., \& Jackson, J. S. (2009). Promoting academic achievement: The role of racial identity in buffering perceptions of teacher discrimination on academic achievement among African American and Caribbean Black adolescents. Journal of Educational Psychology, 101(2), 420-431.

Traoré, R. L. (2004). Colonialism continued: African students in an urban high school in America. Journal of Black Studies, 34(3), 348-369.

Vertovec, S. (1999a). Conceiving and researching transnationalism. Ethnic and Racial Studies, 22(2), 447-462.

Vertovec, S. (1999b). Three meanings of 'diaspora', exemplified among South Asian religions. Diaspora, 6, 277-300.

Warikoo, N. (2004) Race and the teacher-student relationship: Interpersonal connections between West Indian students and their teachers in a New York City high school, Race Ethnicity and Education, 7(2), 135-147.

Washington Cherry, A. (2015). Spaces of possibilities: Using diaspora as a tool to unravel complex ideological frameworks that impact diasporic encounters among African Americans, Afro-Latinas/os, and Latinas/os of African descent in a Prince George's county, Maryland public middle school. Transforming Anthropology: Journal of the Association of Black Anthropologists, 23(1), 28-42.

Waters, M. C. (1994). Ethnic and racial identities of second generation Black immigrants in New York City. International Migration Review, 28(4), 795820.

Williamson, S. Y. (2010). Within-group ethnic differences of Black male STEM majors and factors affecting their persistence in college. Journal of International \& Global Studies, 1, 45-73. 


\section{Appendix A: Inclusion/Exclusion Criterion}

\begin{tabular}{|c|c|c|c|}
\hline & Criteria & Include & Exclude \\
\hline & Date & Published between 1990-2015 & Published prior to 1990 \\
\hline & $\begin{array}{l}\text { Topic/ } \\
\text { Context of } \\
\text { Findings }\end{array}$ & $\begin{array}{l}\text { Topic and findings addressing the } \\
\text { educational experiences of Black } \\
\text { immigrants in the United States; } \\
\text { educational experiences reflecting any } \\
\text { grade level of the P-20 U.S. education } \\
\text { pipeline. }\end{array}$ & $\begin{array}{l}\text { Topic and findings } \\
\text { unrelated to inclusion } \\
\text { criteria }\end{array}$ \\
\hline & Participants & $\begin{array}{l}\text { Black immigrants or educators working } \\
\text { with Black immigrants as research } \\
\text { participants, including first generation } \\
\text { immigrants or the children of immigrants } \\
\text { (other populations may be a part of the } \\
\text { research sample as well as a comparison } \\
\text { group). }\end{array}$ & $\begin{array}{l}\text { Participants unrelated to } \\
\text { inclusion criteria. }\end{array}$ \\
\hline & $\begin{array}{l}\text { Publication } \\
\text { Language }\end{array}$ & English & Non-English \\
\hline & $\begin{array}{l}\text { Publication } \\
\text { Type }\end{array}$ & $\begin{array}{l}\text { Primary empirical studies (qualitative, } \\
\text { quantitative, mixed methods) in the form of } \\
\text { peer reviewed journal articles. }\end{array}$ & $\begin{array}{l}\text { Literature reviews or other } \\
\text { syntheses, reports, books, } \\
\text { conference proceedings, or } \\
\text { unpublished dissertations }\end{array}$ \\
\hline
\end{tabular}

\section{Appendix B: Dataset of Studies}

1. Adeniji-Neill, D. (2011). Omolúàbí: The way of human being: An African philosophy's impact on Nigerian Voluntary immigrants' educational and other life aspirations. İrìnkèrindò: A Journal of African Migration, 5, 1-28.

2. Albertini, V. L. (2004). Racial mistrust among immigrant minority students. Child and Adolescent Social Work Journal, 21(4), 311-331.

3. Alfred, M. V. (2014). Sociocultural contexts and learning: Anglophone Caribbean immigrant women in U.S. postsecondary education. Adult Education Quarterly, 53(4), 242-260.

4. Allen, K. M., Jackson, I., \& Knight, M. G. (2012). Complicating culturally relevant pedagogy: Unpacking West African immigrants' cultural identities. International Journal of Multicultural Education, 14(2), 1-28. 
5. Anglin, D. M., \& Wade, J. C. (2007). Racial socialization, racial identity, and Black students' adjustment. Cultural Diversity and Ethnic Minority Psychology, 13(3), 207-215.

6. Awokoya, J. T. (2012). Identity constructions and negotiations among 1.5- and second-generation Nigerians: The impact of family, school, and peer contexts. Harvard Educational Review, 82(2), 255-281.

7. Barnett, M. D., Sonnert, G., \& Sadler, P. M. (2012). More like us: The effect of immigrant generation on college success in mathematics. International Migration Review, 46(4), 891-918.

8. Bennett, P. R., \& Lutz, A. (2009). How African American is the net Black advantage? Differences in college attendance among immigrant Blacks, native Blacks, and whites. Sociology of Education, 82, 70-100.

9. Burrell, J. O., Fleming, L., Fredericks, A. C., \& Moore, I. (2015). Domestic and international student matters: The college experiences of Black males majoring in engineering at an HBCU. The Journal of Negro Education, 84(1), 40-55.

10. Byrd, W. C., Brunn-Bevel, R. J., \& Sexton, P. R. (2014). 'We don't all look alike': The academic performance of Black student populations at elite colleges. $D u$ Bois Review, 11(2), 353-385.

11. Calzada, E., Barajas-Gonzalez, R. G., Dawson-McClure, S., Huang, K. -Y., Palamar, J., Kamboukos, D., \& Brotman, L. M. (2015). Early academic achievement among American low-income Black students from immigrant and non-immigrant families. Prevention Science, 16(8), 1159-1168.

12. Carhill, A., Suarez-Orozco, C., \& Paez, M. (2008). Explaining English language proficiency among adolescent immigrant students. American Educational Research Journal, 45(4), 1155-1179.

13. Charles, C. Z., Kramer, R. A., Torres, K. C., \& Brunn-Bevel, R. J. (2015). Intragroup heterogeneity and Blackness: Effects of racial classification, immigrant origins, social class, and social context on the racial identity of elite college students. Race and Social Problems, 7(4), 281-299.

14. Clachar, A. (2004). The construction of Creole-speaking students' linguistic profile and contradictions in ESL literacy programs. Teachers of English to Speakers of Other Languages Quarterly, 38(1), 153-165.

15. Cone, N., Buxton, C., Lee, O., \& Mahotiere, M. (2014). Negotiating a sense of identity in a foreign land: Navigating public school structures and practices that often conflict with Haitian culture and values. Urban Education, 49(3), 263-296.

16. Conger, D., Schwartz, A. E., \& Stiefel, L. (2011). The effect of immigrant communities on foreign-born student achievement. International Migration Review, 45(3), 675-701.

17. Constantine, M. G., Anderson, G. M., Berkel, L. A., Caldwell, L. D., \& Utsey, S. O. (2005). Examining the cultural adjustment experiences of African international college students: A qualitative analysis. Journal of Counseling Psychology, 52(1), 57-66. 
18. Coutinho, M. T., \& Blustein, D. L. (2014). Cape Verdean immigrants' career development and school engagement: Perceived discrimination as a moderator. Journal of Career Development, 41(4), 341-358.

19. Coutinho, M. T., \& Koinis-Mitchell, D. (2014). Black immigrants and school engagement: Perceptions of discrimination, ethnic identity, and American identity. Journal of Black Psychology, 40(6), 520-538.

20. De Feyter, J. J., \& Winsler, A. (2009). The early developmental competencies and school readiness of low-income, immigrant children: Influences of generation, race/ethnicity, and national origins. Early Childhood Research Quarterly, 24, 411431.

21. De Walt, P. S. (2011). In search of an authentic African American and/or Black identity: Perspectives of first generation U.S.-born Africans attending a predominantly white institution. Journal of Black Studies, 42(3), 479-503.

22. Deaux, K., Bikmen, N., Gilkes, A., Ventuneac, A., Payne, Y. A., \& Steele, C. M. (2007). Becoming American: Stereotype threat effects in Afro-Caribbean immigrant groups. Social Psychology Quarterly, 70(4), 384-404.

23. Doucet, F. (2005). Divergent realities: The home and school lives of Haitian immigrant youth. Journal of Youth Ministry, 3(2), 37-65.

24. Fawzi, M. C. S., Betancourt, T. S., Marcelin, L., Klopner, M., Munir, K., Muriel, A. C., ... Mukherjee, J. S. (2009). Depression and post-traumatic stress disorder among Haitian immigrant students: Implications for access to mental health services and educational programming. BMC Public Health, 9 (482), 1-11.

25. Feliciano, C. (2009). Education and ethnic identity formation among children of Latin American and Caribbean immigrants. Sociological Perspectives, 52(2), 135158.

26. Fisher, E. J. (2005). Black student achievement and the oppositional culture model. The Journal of Negro Education, 74(3), 201-209.

27. Foster, K. M. (2005). Gods or vermin: Alternative readings of the African American experience among African and African American college students. Transforming Anthropology, 13(1), 34-47.

28. Fries-Britt, S., George Mwangi, C. A., \& Peralta, A. M. (2014a). The acculturation experiences of foreign-born students of color in physics. Journal of Student Affairs Research and Practice, 51(4), 459-471.

29. Fries-Britt, S., George Mwangi, C. A., \& Peralta, A. M. (2014b). Learning race in a U.S. context: An emergent framework on the perceptions of race among foreignborn students of color. Journal of Diversity in Higher Education, 7(1), 1-13.

30. George Mwangi, C. A., \& Fries-Britt, S. (2015) Black within Black: The perceptions of Black immigrant collegians and their U.S. college experience. About Campus, 20(2), 16-23.

31. Gilbert, S. (2009). A study of Ogbu and Simons' thesis regarding Black children's immigrant and non-immigrant status and school achievement. The Negro Educational Review, 60(1-4), 71-91. 
32. Glick, J. E., \& Hohmann-Marriott, B. (2007). Academic performance of young children in immigrant families: The significance of race, ethnicity, and national origins. International Migration Review, 41(2), 371-402.

33. Griffin, K. A., \& Mclntosh, K. L. (2015). Finding a fit: Understanding Black immigrant students' engagement in campus activities. Journal of College Student Development, 56(3), 243-260.

34. Griffin, K., Cunningham, E., \& George Mwangi, C.A. (2015). Defining diversity: Ethnic differences in Black students' perceptions of racial climate. Journal of Diversity in Higher Education, 9(1), 34-49.

35. Griffin, K., del Pilar, W., Mclntosh, K., \& Griffin, A. (2012). "Oh, of course I'm going to go to college": Understanding how habitus shapes the college choice process of Black immigrant students. Journal of Diversity in Higher Education, 5(2), 96-111.

36. Hagy, A. P., \& Staniec, J. (2002). Immigrant status, race, and institutional choice in higher education. Economics of Education Review, 21(4), 381-392.

37. Hailu, T. E., \& Ku, H. Y. (2014). The adaptation of the Horn of Africa immigrant students in higher education. The Qualitative Report, 19(28), 1-19.

38. Han, W. (2006). Academic achievements of children in immigrant families. Educational Research and Review, 1(8), 286-318.

39. Haynie, A. C. (2002). Not 'just Black' policy considerations: The influence of ethnicity on pathways to academic success amongst Black undergraduates at Harvard University. Journal of Public and International Affairs, 13, 40-62.

40. Hernandez, K. A. C., \& Murray-Johnson, K. K. (2015). Towards a different construction of Blackness: Black immigrant scholars on racial identity development in the United States. International Journal of Multicultural Education, 17(2), 53-72.

41. Hersi, A. A. (2011) Immigration and resiliency: Unpacking the experiences of high school students from Cape Verde and Ethiopia. Intercultural Education, 22(3), 189-202.

42. Jenkins, A., Harburg, E., Weissberg, N. C., \& Donnelly, T. (2004). The influence of minority group cultural models on persistence in college. Journal of Negro Education, 73, 69-80.

43. Joseph, N., \& Hunter, C. D. (2011). Ethnic-racial socialization messages in the identity development of second-generation Haitians. Journal of Adolescent Research, 26(3), 344-380.

44. Kao, G. (2004). Parental influences on the educational outcomes of immigrant youths. International Migration Review 38, 427-449.

45. Kasinitz, P. (2008). Becoming American, becoming minority, getting ahead: The role of racial and ethnic status in the upward mobility of the children of immigrants. The ANNALS of the American Academy of Political and Social Science, 620(1), 253-269.

46. Keller, U., \& Tillman, K. H. (2008). Post-secondary educational attainment of immigrant and native youth. Social Forces, 87(1), 121-152. 
47. Kia-Keating, M., \& Ellis, B. H. (2007). Belonging and connection to school in resettlement: Young refugees, school belonging, and psychosocial adjustment. Clinical Child Psychology and Psychiatry, 12(1), 29-43.

48. Knight, M. G., Roegman, R., \& Edstrom, L. (2015). My American dream: The interplay between structure and agency in West African immigrants' educational experiences in the United States. Education and Urban Society, 1-25.

49. Lee, E. M., \& Kao, G. (2009). Less bang for the buck? Cultural capital and immigrant status effects on kindergarten academic outcomes. Poetics, 37, 201226.

50. Lee, J. J., \& Rice, C. (2007) Welcome to America? International student perceptions of discrimination. Higher Education, 53(3), 381-409.

51. Massey, D. S., Mooney, M., Torres, K. C., \& Charles, C. Z. (2007). Black immigrants and Black natives attending selective colleges and universities in the United States. American Journal of Education, 113(2), 243-271.

52. McLean, C. A. (2010). A space called home: An immigrant adolescent's digital literacy practices. Journal of Adolescent \& Adult Literacy, 54(1), 13-22.

53. McFarlane, T. A. (2010). Experiencing difference, seeking community: Racial, panethnic, and national identities among female Caribbean-born U.S. college students. American Review of Political Economy 8(2), 87-114.

54. Mugisha, V. M. (2015). Engaged African refugee youth negotiating schooling in America: An inquiry into the influence of culture and social structure. International Journal of Education, 7(1), 165-194.

55. Murray-Johnson, K. K. (2013). Cultural (de)coding and racial identity among women of the African diaspora. Adult Learning, 24(2), 55-62.

56. Nicholas, G., DeSilva, A., \& Rabenstein, K. (2009). Educational attainment of Haitian immigrants. Urban Education, 44(6), 664-686.

57. Nicholas, T., Stepkick, A., \& Stepkick, D. (2008). "Here's your diploma mom!" Family obligation and multiple pathways to success. Annals of the American Academy of Political and Social Science, 620, 237-252.

58. Njue, J., \& Retish, P. (2010). Transitioning academic and social performance of African immigrant students in an American high school. Urban Education, 45(3), 347-370.

59. Okpalaoka, C. L., \& Dillard, C. B. (2012). (Im)migrations, relations, and identities of African peoples: Toward an endarkened transnational feminist praxis in education. Educational Foundations, 26(1-2), 121-142.

60. Owens, J., \& Lynch, S. M. (2012). Black and Hispanic immigrants' resilience against negative-ability racial stereotypes at selective colleges and universities in the United States. Sociology of Education, 85(4), 303-325.

61. Peguero, A. A., Shekarkhar, Z., Popp, A. M., \& Koo, D. J. (2015). Punishing the children of immigrants: Race, ethnicity, generational status, student misbehavior, and school discipline, Journal of Immigrant \& Refugee Studies, 13(2), 200-220.

62. Perreira, K. M., Harris, K. M., \& Lee, D. (2006). Making it in America: High school completion by immigrant and native youth. Demography, 43(3), 511-536. 
63. Onwughalu, M., \& Phinney, J. S. (1996). Racial identity and perception of American ideals among African American and African students in the United States. International Journal of Intercultural Relations, (20)2, 127-140.

64. Portes, A., \& Schauffler, R. (1994). Language and the second generation: Bilingualism yesterday and today. The International Migration Review, 28(4), 640661.

65. Raleigh, E., \& Kao, G. (2010). Do immigrant minority parents have more consistent college aspirations for their children? Social Science Quarterly, 91(4), 1083-1102.

66. Rivers, N. M. (2012). No longer sojourners: The complexities racial ethnic identity, gender, and generational outcomes for sub-Saharan Africans in the USA. International Journal of Population Research, 1-14.

67. Rong, K. L., \& Brown, F. (2001). The effects of immigrant generation and ethnicity on educational attainment among young African and Caribbean Blacks in the United States. Harvard Educational Review, 71(3), 536-565.

68. Roopnarine, J. L., Krishnakumar, A., Metindogan, A., \& Evans, M. (2006). Links between parenting styles, parent-child academic interaction, parent-school interaction, and early academic skills and social behaviors in young children of English-speaking Caribbean immigrants. Early Childhood Research Quarterly, 21, 238-252.

69. Roubeni, S., de Haene, L., Keatley, E., Shah, N., \& Rasmussen, A. (2015). "If we can't do it, our children will do it one day": A qualitative study of West African immigrant parents' losses and educational aspirations for their children. American Educational Research Journal, 52(2), 275-305.

70. Roxas, K., \& Roy, L. (2012). "That's how we roll:" A case study of a recently arrived refugee student in an urban high school. Urban Review, 44, 468-486.

71. Rumbaut, R. G. (1994). The crucible within: Ethnic identity, self-esteem, and segmented assimilation among children of immigrants. International Migration Review, 28(4), 748-794.

72. Sanchez, D. (2013). Racial and ego identity in Black Caribbean college students. Journal of Diversity in Higher Education, 6(2), 115-126.

73. Sofo, S., Nandzo, J., Asola, E. F., \& Ajongbah, K. S. (2013). African immigrant students' experiences in American physical education classes. International Journal of Arts and Commerce, 2(10), 59-70.

74. Tauriac, J. J., \& Liem, J. H. (2012). Exploring the divergent academic outcomes of immigrant-origin Black undergraduates. Journal of Diversity in Higher Education, 5(4), 244-258.

75. Thomas, K. J. A. (2009). Parental characteristics and the schooling progress of the children of immigrant and U.S.-born Blacks. Demography, 46(3), 513-534.

76. Thomas, K. J. A (2012a). Race and schooling enrollment among the children of African immigrants in the United States. International Migration Review, 46(1), 37-60.

77. Thomas, K. J. A. (2012b). Migration processes, familial characteristics, and schooling dropout among Black youths. Demography, 49(2), 477-498. 
78. Thomas, O. N., Howard Caldwell, C., Faison, N., \& Jackson, J. S. (2009). Promoting academic achievement: The role of racial identity in buffering perceptions of teacher discrimination on academic achievement among African American and Caribbean Black adolescents. Journal of Educational Psychology, 101(2), 420-431.

79. Traoré, R. L. (2004). Colonialism continued: African students in an urban high school in America. Journal of Black Studies, 34(3), 348-369.

80. Traoré, R. L. (2006). Voices of African students in America: "We're not from the jungle." Multicultural Perspectives, 8(2), 29-34.

81. Tseng, V. (2004). Family interdependence and adjustment in college: Youth from immigrant and U.S.-born families. Child Development, 75(3), 966-983.

82. Warikoo, N. (2004) Race and the teacher-student relationship: Interpersonal connections between West Indian students and their teachers in a New York City high school, Race Ethnicity and Education, 7(2), 135-147.

83. Washington Cherry, A. (2015). Spaces of possibilities: Using diaspora as a tool to unravel complex ideological frameworks that impact diasporic encounters among African Americans, Afro-Latinas/os, and Latinas/os of African descent in a Prince George's county, Maryland public middle school. Transforming Anthropology: Journal of the Association of Black Anthropologists, 23(1), 28-42.

84. Waters, M. C. (1994). Ethnic and racial identities of second generation Black immigrants in New York City. International Migration Review, 28(4), 795-820.

85. Williamson, S. Y. (2010). Within-group ethnic differences of Black male STEM majors and factors affecting their persistence in college. Journal of International \& Global Studies, 1, 45-73 


\section{Appendix C: Summary of Dataset Characteristics}

\begin{tabular}{|c|c|}
\hline Characteristic & Percentage of articles $(n=85)$ \\
\hline \multirow[t]{5}{*}{ Publication Year } & $1990-1995-3.5 \%(n=3)$ \\
\hline & $1996-2000-1.2 \%(n=1)$ \\
\hline & $2001-2005-18.8 \%(n=16)$ \\
\hline & $2006-2010-31.8 \%(n=27)$ \\
\hline & $2011-2015-44.7 \%(n=38)$ \\
\hline \multirow{14}{*}{$\begin{array}{l}\text { Theoretical Framework } \\
\text { ( } \mathrm{N} \text { will be greater than } 85 \\
\text { because some studies used } \\
\text { multiple frameworks and so } \\
\text { were counted under more than } \\
\text { one category.) }\end{array}$} & $\begin{array}{l}\text { Assimilation/Acculturation/Adaptation/Adjustment/Incorporatio } \\
\mathrm{n}(\mathrm{n}=24)\end{array}$ \\
\hline & Cultural Ecology Theory $(n=6)$ \\
\hline & Racial/Ethnic Identity Development $(n=12)$ \\
\hline & Postcolonial/Diasporic $(n=5)$ \\
\hline & Critical Race (CRT, CRFT, Intersectionality) $(n=4)$ \\
\hline & Stereotype Threat $(n=2)$ \\
\hline & Immigrant Optimism/Advantage $(n=5)$ \\
\hline & Agency/Self-Efficacy $(n=3)$ \\
\hline & Habitus/Forms of Capital $(n=3)$ \\
\hline & Neo-racism $(\mathrm{n}=2)$ \\
\hline & (Sense of) Belonging ( $n=2)$ \\
\hline & None $(n=10)$ \\
\hline & Structuration Theory/Social Structures and Culture $(n=4)$ \\
\hline & $\begin{array}{l}\text { Other }(n=18) \\
\text { Sociocultural Theory; Motivation Theory; Indigenous } \\
\text { Knowledge; Multiple Worlds; Racial Group Consciousness; } \\
\text { Racial Uplift; Campus Racial Climate; Ethnic-racial } \\
\text { Socialization; Conservation of Resources Theory; } \\
\text { Interactionalist Student Departure; Social Learning; Family } \\
\text { Interdependence; Identity Matching; Racial Mistrust; Aspect } \\
\text { Hypothesis; Integrative model of the Development of Children } \\
\text { of Color; Psychosocial Health Outcomes; Integrative } \\
\text { Ecological model of Child Development) }\end{array}$ \\
\hline \multirow[t]{2}{*}{ Research Design } & Qualitative - 45.9\% ( $n=39)$ \\
\hline & Quantitative $-47 \% \quad(n=40)$ \\
\hline
\end{tabular}




\begin{tabular}{|c|c|}
\hline & Mixed Methods $-7.1 \%(n=6)$ \\
\hline \multirow{4}{*}{$\begin{array}{l}\text { Black Immigrant Region of } \\
\text { Origin }\end{array}$} & Region not indicated/Mixed Regions $-38.8 \%(n=33)$ \\
\hline & Africa $-29.4 \%(n=25)$ \\
\hline & Caribbean $-27.1 \%(n=23)$ \\
\hline & Latin America - $4.7 \%(n=4)$ \\
\hline \multirow{4}{*}{$\begin{array}{l}\text { Black Immigrant Generation } \\
\text { Studies not indicating } \\
\text { generation status or using a } \\
\text { broad term (e.g., children of } \\
\text { immigrants) are included in } \\
\text { "Does not indicate generation." }\end{array}$} & First Generation $-32.9 \%(n=28)$ \\
\hline & Second Generation $-5.9 \%(n=5)$ \\
\hline & Mix of Generations $-48.2 \%(n=41)$ \\
\hline & Does not indicate generation $-12.9 \%(n=11)$ \\
\hline \multirow[t]{5}{*}{ Comparison Group } & No $-51.8 \%(n=44)$ \\
\hline & $\begin{array}{l}\text { Yes, all other racial and nativity status populations }-17.6 \% \\
(n=15)\end{array}$ \\
\hline & Yes, Americans $-2.4 \%(n=2)$ \\
\hline & Yes, African Americans - 22.3\% $(n=19)$ \\
\hline & Yes, other immigrants $-5.9 \%(n=5)$ \\
\hline \multirow{4}{*}{$\begin{array}{l}\text { Level of Education Pipeline } \\
\text { "College" includes } \\
\text { undergraduate and graduate } \\
\text { levels. }\end{array}$} & Elementary/Middle $-12.9 \%(n=11)$ \\
\hline & Middle/High School - 29.4\% $(n=25)$ \\
\hline & College $-35.3 \%(n=30)$ \\
\hline & Multiple Levels - 22.4\% ( $n=19)$ \\
\hline
\end{tabular}

\section{Author Contact}

Chrystal A. George Mwangi: chrystal@umass.edu University of Massachusetts Amherst, Department of Educational Policy, Research, and Administration, Amherst, MA 01003

Shelvia English: senglis1@umd.edu University of Maryland: College Park, MD 20742 